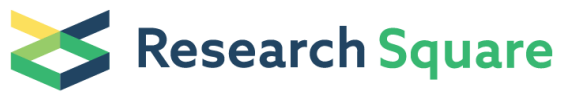 \\ Preprints are preliminary reports that have not undergone peer review. \\ They should not be considered conclusive, used to inform clinical practice, \\ or referenced by the media as validated information.
}

\section{Cardiovascular Disease and Risk of Incident Diabetes Mellitus: Findings from the Hispanic Community Health Study/Study of Latinos (HCHS/SOL)}

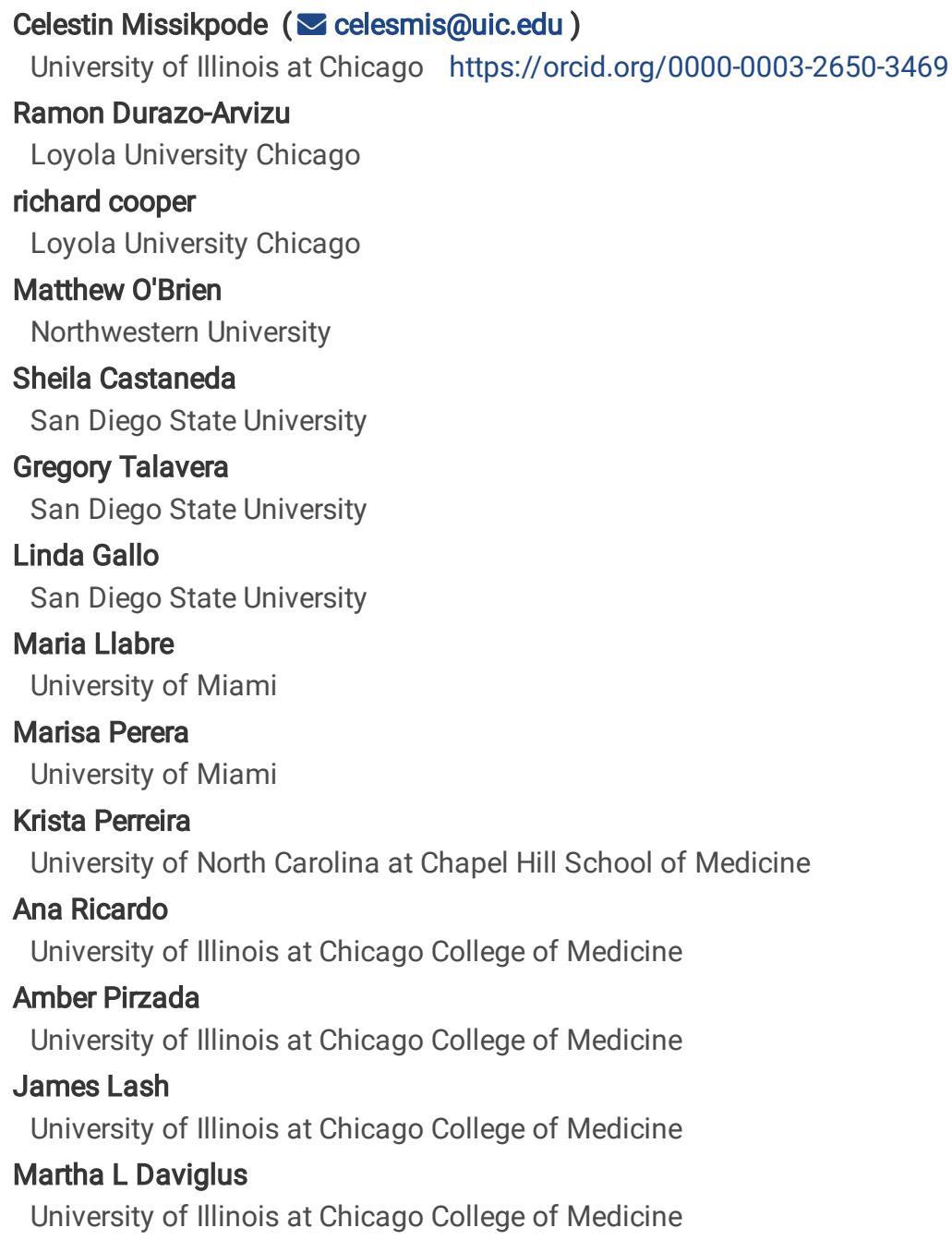

\section{Original investigation}

Keywords: Incident diabetes, Cardiovascular disease, Propensity scores, Cardiovascular medications, Mediation.

Posted Date: February 12th, 2021

DOI: https://doi.org/10.21203/rs.3.rs-180873/v1

License: (c) (1) This work is licensed under a Creative Commons Attribution 4.0 International License. Read Full License 


\section{Abstract}

\section{Introduction}

Studies have reported an association between cardiovascular disease (CVD) and risk of diabetes mellitus (DM). The mechanisms underlying this association remain unclear. We examined the association of CVD with incident DM and assessed the roles of weight gain and medication use as mediating factors.

\section{Methods}

Data from the Hispanic Community Health Study/Study of Latinos (HCHS/SOL) Visit 1 (2008-2011) and Visit 2 (2014-2017) were used to compare incidence of DM among individuals with and without self-reported CVD at Visit 1. A total of 2081 individuals with self-reported CVD were matched to controls free of self-reported CVD at Visit 1 using 1:1 propensity score matching. Covariates included in the propensity model were sociodemographic characteristics, lifestyle factors, comorbid conditions, and study site. The effect of self-reported CVD on incident DM was examined using Generalized Estimating Equation. The mediating effects of weight gain and use of cardiovascular medications were evaluated.

\section{Results}

Covariate distributions were similar among individuals with and without self-reported CVD. The incidence of DM among persons with selfreported CVD was $15.6 \%$ vs. $12.7 \%$ among those without self-reported CVD. Compared to individuals without self-reported CVD, individuals with self-reported CVD had a $28 \%$ increased risk for incident $D M(O R=1.28,95 \% \mathrm{Cl}=1.07,1.52)$. The association between self-reported CVD and DM was mediated by the use of beta-blockers (proportion mediated $=31 \%$ ), statins (proportion mediated=24\%), and diuretics (proportion mediated $=8 \%$ ). We found that weight gain did not explain the observed association.

\section{Conclusions}

Cardiovascular disease was associated with a significant increased risk of incident diabetes. The observed association was partially mediated by some medications used to manage CVD.

\section{Introduction}

The past two decades have seen a dramatic increase in the number of people with diabetes mellitus (DM) worldwide. In 2010, there were 150-220 million people with DM worldwide, and this number is expected to reach 300 million by 2025 [1, 2]. As of 2015, estimates showed that 30.3 million U.S. residents had DM [3], and the prevalence of DM in the U.S. is expected to increase $120 \%$ by 2050 [4]. The increasing prevalence of DM over the next decades is alarming and calls for public health attention.

DM is a well-established and widely recognized risk factor for cardiovascular disease (CVD). However, studies suggest that the relationship may be reciprocal, i.e., that CVD also increases the risk of developing DM $[5,6]$. The mechanisms underlying the latter association are not well understood. Several posited mechanisms for the association of CVD with DM include gluconeogenesis and glycogenolysis resulting from neurohormonal activation usually present in CVD, catecholamine-induced increase insulin resistance, shared inflammatory pathways in CVD and DM, and physical inactivity [6]. None of these hypothesized explanations have been formally tested and several other mechanisms may be involved as well. For instance, medications used for secondary prevention of CVD might sometimes have unintended health consequences. Prior mechanistic, clinical, and epidemiologic research suggests that commonly used pharmacological agents such as betablockers, statins, and diuretics may cause metabolic derangements leading to increased risk for incident DM but findings have been inconclusive [7-9]. Furthermore, the physical impairment associated with CVD may limit the capacity of people with CVD to engage in physical activity [10] and promote weight gain [11], which are both associated with elevated risk of DM. The extent to which the association of CVD with incident DM can be attributed to weight gain or cardiovascular medications is not known.

In the current study, we analyzed data from the Hispanic Community Health Study/ Study of Latinos (HCHS/SOL), using propensity score (PS) methods to test the hypothesis that CVD was associated with increased risk of incident DM. We further investigated whether this association was mediated by weight gain or the use of beta-blockers, statins, and diuretics. This analytical framework may provide supportive evidence for the association of CVD with subsequent DM and elucidate potential underlying mechanisms.

\section{Methods}

\section{Study population}


The Hispanic Community Health Study/Study of Latinos (HCHS/SOL) is a population-based longitudinal study in the United States that enrolled participants between 2008 and 2011 [12]. Participants were self-identified Hispanic/Latino individuals aged 18-74 years at baseline, randomly selected from households in the Bronx, New York; San Diego, California; Chicago, Illinois; and Miami, Florida. A stratified, two-stage sampling method was used to select households. The design oversampled individuals aged 45 to 74 years. A total of 16,415 participants were enrolled in the study. Each participating institutional review board approved the study, and written informed consent was obtained from all participants.

We restricted our study population to individuals without diabetes mellitus (DM) at baseline (Visit 1) and who participated in Visit 2 data collection. Of the 16,415 participants at Visit 1, we excluded 4792 (29.2\%) individuals who did not participate in the Visit 2 data collection. Of those who participated in Visit 2 data collection ( $\mathrm{N}=11623$ ), we excluded 2401 with diabetes (as defined below) and 8 with missing data on diabetes at Visit 1. We further excluded 537 individuals due to missing information on covariates at Visit 1 and diabetes at Visit 2, thus yielding 8677 eligible individuals (Figure 1). We restricted our main analysis to a subset of 4162 individuals: 2081 individuals who selfreported prior cardiovascular disease (CVD) at baseline, and 2081 individuals who did not report CVD but had similar probability or propensity to self-report CVD at baseline, as described below. This approach was taken to address differential loss to follow-up because $3163(31.6 \%)$ participants free of self-reported CVD were lost to follow-up compared to 798 (25.4\%) participants with self-reported CVD $(\mathrm{p}<.0001)$. By matching, we created a control group of individuals without self-reported CVD that are comparable to individuals with selfreported CVD with respect to observed covariates.

\section{Exposure and outcome assessment}

Self-reported CVD at baseline (Visit 1) was defined as the presence of self-reported coronary heart disease, cerebrovascular events, peripheral artery disease, or heart failure. Incident DM at 6-year follow-up (visit 2) was defined by any of the following American Diabetes Association (ADA) criteria: fasting time > 8 hours and fasting blood glucose of $126 \mathrm{mg} / \mathrm{dL}$ or greater; fasting time less than 8 hours and fasting glucose of $200 \mathrm{mg} / \mathrm{dL}$ or greater; post-OGTT glucose of $200 \mathrm{mg} / \mathrm{dL}$ or greater; hemoglobin A1C of $6.5 \%$ or greater; or use of antihyperglycemic medications [13].

\section{Covariates}

At HCHS/SOL Visit 1, sociodemographic data including age, sex, Hispanic/Latino background, level of educational attainment, marital status, and health insurance coverage were self-reported. Additional self-reported information assessed at Visit 1 included smoking status, the average number of cigarettes smoked per day, alcohol use, family history of diabetes, gestational diabetes, and 24-hour dietary recalls. Blood pressure, height, weight, and waist circumference were ascertained on physical examination. Physical activity was assessed using Actical accelerometers and categorized as high, moderate, and low. Venous blood specimens were also collected at Visit 1 and analyzed to measure serum creatinine, blood glucose, hemoglobin A1C, total and HDL cholesterol, and triglycerides. Alternate Healthy Eating Index 2010 (AHEl-2010), a measure of dietary quality, was calculated from the 24-hour dietary recalls. Height and weight were used to calculate body mass index (BMI) as weight (in kilograms) divided by height (in meters) squared. Hypertension was defined as systolic blood pressure 140 $\mathrm{mm} \mathrm{Hg}$ or greater, diastolic blood pressure $90 \mathrm{~mm} \mathrm{Hg}$ or greater, or use of antihypertensive medications. Prediabetes was defined as fasting time $>8$ and fasting blood glucose in range $100-125 \mathrm{mg} / \mathrm{dL}$, or post-OGTT glucose in range $140-199 \mathrm{mg} / \mathrm{dL}$, or $5.7 \% \leq \mathrm{A} 1 \mathrm{C}<6.5 \%$. The diagnosis of metabolic syndrome was made when three or more of the following factors were present: hypertension, triglyceride $\geq 150$ $\mathrm{mg} / \mathrm{dL}$, low HDL (HDL cholesterol $<40 \mathrm{mg} / \mathrm{dL}$ in men and $<50 \mathrm{mg} / \mathrm{dL}$ in women), fasting blood glucose $\geq 100 \mathrm{mg} / \mathrm{dL}$, and waist circumference $\geq 102 \mathrm{~cm}$ in men and $\geq 88 \mathrm{~cm}$ in women. Kidney function was assessed using estimated glomerular filtration rate (eGFR in $\mathrm{mL} / \mathrm{min} / 1.73 \mathrm{~m}^{2}$ ) and classified as normal (eGFR $\left.\geq 90\right)$, mild kidney damage ( $\left.60 \leq \mathrm{GFR}<90\right)$, moderate kidney damage (30 $\left.\leq \mathrm{GFR}<60\right)$, severe kidney damage $(15 \leq \mathrm{eGFR}<30)$, and end-stage renal disease $(\mathrm{eGFR}<15)$.

\section{Mediating variables}

We examined whether the association between self-reported CVD and incident DM was mediated by medication classes such as betablockers, statins, and diuretics as well as by weight gain. HCHS/SOL obtained information on medications taken in the past 4 weeks prior to the baseline examination. Participants were asked to bring in all prescribed or over-the-counter medications. The medication information was used to uniquely identify drug products based on their generic ingredients and then assigned to their medication classes. Data were also gathered on weight at both Visit 1 and Visit 2, and weight gain was defined as the difference in weight between the two visits.

\section{Selection of the analytical sample}

We matched HCHS/SOL participants based on their probability or propensity to self-report CVD at baseline. The propensity score (PS) is the conditional probability of being exposed (e.g., CVD) given a vector of measured covariates, and can be used to adjust for selection bias when 
assessing causal effects in observational studies [14]. We estimated the PS for self-reported CVD for each participant using a multivariable logistic regression model, in which self-reported CVD was modeled using all baseline covariates in Table 1, as well as interaction effects. We then used the estimated PS to match participants without self-reported CVD to participants with self-reported CVD who had very similar PS using greedy algorithms (nearest best match) [15]. Under the greedy algorithms, matches with the highest digit on PS are the best ones and selected first, and then the next-best matches are selected in a sequential process until no further matches can be made [15]. In our matching algorithm, we first attempted to match each individual without self-reported CVD with a self-reported CVD individual who had a similar PS to eight decimal places. Then we removed those matched pairs of individuals and repeated the process matching to seven, six, five, four, three, two, and one decimal places.

\section{Assessment of baseline covariate balance}

We compared the balance of all baseline covariates in Table 1 between individuals with and without self-reported CVD before and after PS matching using Pearson Chi-square. We used the standardized difference to compare the mean PS score before and after matching, which directly quantifies the bias in the mean PS across the two groups (individuals with and without self-reported CVD), expressed as a percentage of the pooled standard deviation (SD). Before matching, the mean PS for people without self-reported CVD ( $N=6498)$ was 0.193 $(\mathrm{SE}=0.154)$ and in those with self-reported CVD $(\mathrm{N}=2179)$ was $0.348(\mathrm{SE}=0.187)$, with an associated standardized difference of $90.6 \%$ ( $\mathrm{t}-$ test $p$-value, <.0001). After matching, the mean PS for individuals without self-reported CVD ( $N=2081)$ was 0.329 (SE=0.171) and for those with self-reported CVD $(\mathrm{N}=2081)$ was 0.330 ( $\mathrm{SE}=0.171)$, which yields a standardized difference of $0.4 \%$ (t-test $p$-value 0.88$)$.

\section{Statistical analysis}

A Generalized Estimating Equation (GEE) was used to calculate the odds ratio and corresponding $95 \%$ confidence intervals for the association between self-reported CVD and incident DM. This method allowed accounting for the lack of independence induced by the propensity score matching. To assess the robustness of our findings regarding the effect of self-reported CVD on incident DM, we conducted sensitivity analyses using alternative analytic approaches. First, to address concerns about self-report of CVD, we also estimated the effect of CVD on DM risk by using major electrocardiogram (ECG) abnormalities at Visit 1 to define CVD (See footnote Table 1 for ECG findings used to define CVD). A subset of 591 individuals with documented major ECG abnormalities at Visit 1 suggestive of CVD was matched to 591 individuals without major ECG abnormalities using 1:1 PS matching. Second, we analyzed data from the unmatched sample ( $N=8677)$ by performing weighted logistic regression adjustment to estimate the association of self-reported CVD and ECG-defined CVD with incident DM; these analyses adjusted for covariates used in the logistic regression model for PS. Because individuals were matched regardless of their sampling units, analyses for the matched data were not weighted.

We also examined whether the association between self-reported CVD and incident DM was mediated by either weight gain or cardiovascular medication classes such as beta-blockers, statins, and diuretics. For each mediating factor, we decomposed the total effect into two different pathways: (1) the effect of self-reported CVD on DM through the mediating pathway (i.e., the natural indirect effect) and 2) the effect of self-reported CVD on DM that is not through the mediating pathway (i.e., the natural direct effect). For each mediator, we determined the proportion mediated by calculating the ratio of the log indirect effect and the log total effect. The mediation analysis was conducted using semiparametric methods $[16,17]$. For each medication class, we estimated the total effect by regressing DM on selfreported CVD using GEE model accounting for matching and follow-up time between Visit 1 and Visit 2. To estimate the natural direct effect of self-reported CVD, we regressed DM on self-reported CVD using GEE model in a subsample of individuals who were not on that medication. Restricting the analysis to medication free individuals ensured that we isolated the effect of self-reported CVD that is not mediated by the use of that medication (i.e., direct effect). Finally, the natural indirect effect was determined by subtracting the direct effect from the total effect $[16,17]$. All analyses were conducted using SAS version 9.4 (SAS Institute, Inc., Cary, NC).

\section{Results}

The mean (+SE) age of the 4162 PS-matched individuals was 52 (SE=10.6) years (median: 53; range: 18-74), and 34.0\% were males. Table 1 compares baseline characteristics by CVD status before and after PS matching. Before matching, individuals with self-reported CVD were more likely to be female, older, less educated, and more likely to be insured as compared to individuals without self-reported CVD. Individuals with self-reported CVD were more likely to have DM risk factors including prediabetes, metabolic syndrome, obesity, family history of DM, high cholesterol, and cigarette smoking at baseline. They more often had hypertension and chronic kidney disease at baseline. Of the 2179 individuals with self-reported CVD and 6498 individuals without self-reported CVD at baseline, 345 (15.8\%) and 644 (9.9\%) developed incident DM respectively at 6-year follow-up $(p<.0001)$.

After matching, individuals with and without self-reported CVD were very similar with regards to baseline covariates (Table 1). The standardized difference for the mean PS was $0.4 \%$ in absolute value, thus demonstrating an excellent balance in measured covariates 
across the two groups. The distributions of the PS score for individuals with and without self-reported CVD matched were nearly identical (Figure 2). In the matched cohort, two-thirds of beta-blocker users and about three in five statin and diuretics users self-reported CVD (Table 2). Significantly higher proportions of people who were on beta-blockers, statins, or diuretics at baseline developed DM at 6-year follow-up (Table 2).

At 6-year follow-up, 325 (15.6\%) of the 2081 individuals with self-reported CVD and 265 (12.7\%) of the 2081 individuals without self-reported CVD developed incident DM (Figure 1). Compared to individuals without self-reported CVD, individuals with self-reported CVD had a $28 \%$ increased risk for incident $D M(O R=1.28,95 \% \mathrm{Cl}=1.07,1.52)$ (Table 3$)$. The association was stronger when major $E C G$ abnormalities were used to define CVD $(O R=1.39,95 \% \mathrm{Cl}=1.01,1.93)$. When we adjusted for baseline covariates in the full (unmatched) cohort $(\mathrm{N}=8677)$, we observed lower and borderline significant effects of CVD on incident DM $(\mathrm{OR}=1.18,95 \% \mathrm{Cl}=0.93,1.49$ and $\mathrm{OR}=1.33,95 \% \mathrm{Cl}=0.94,1.89$, for self-reported CVD and ECG-defined CVD, respectively).

Our results showed evidence of mediation of the effect of self-reported CVD through a pathway involving cardiovascular medication use (Table 3). The largest indirect effect was for beta-blockers (proportion mediated $=31 \%$ ), followed by statins (proportion mediated $=24 \%$ ), and diuretics (proportion mediated $=8 \%$ ). Weight gain did not appear to mediate the excess risk of DM associated with self-reported CVD: from baseline to the six-year follow-up visit, individuals with self-reported CVD had a mean weight gain (in kilograms) that was similar to that observed in individuals without self-reported CVD $(0.76 \pm 6.99$ and $0.74 \pm 6.75$, respectively, $p=0.91)$.

\section{Discussion}

Our findings provide evidence that cardiovascular disease (CVD) is associated with increased risk of diabetes mellitus (DM). This study showed that the association between cardiovascular disease and incident diabetes mellitus was partially mediated by cardiovascular medications such beta-blockers, statins, and diuretics.

Both propensity score (PS) matching and regression adjustment method showed similar results, which were marginally significant for the latter. Methods based on PS have theoretical advantages over traditional regression methods used to adjust for baseline differences between exposed and non-exposed groups in observational studies $[18,19]$. A common concern in covariate adjustment methods is that such models might be overfitted when there are too many covariates. Furthermore, the statistical literature argues that covariate adjustment methods cannot reliably adjust for differences in observed covariates across groups when the differences in the distribution of these covariates are substantial $[18,19]$. In our study, individuals with and those without self-reported CVD (full sample) were considerably different as evidenced by the approximatively $91 \%$ standardized difference in their PS. Thus, individuals with and those without self-reported CVD markedly differed on baseline characteristics and regression adjustment may not reliably account for these differences because the fitted regression model might be interpolating between two nearly distinct groups.

A similar relationship between CVD and incident DM has been found in other studies. A previous study reported that individuals with CVD and without co-morbid DM have 35\% increased risk of subsequently developing incident DM after controlling for other risk factors [5]. A large cohort study followed a nondiabetic population after acute cardiovascular event and found a significant increased risk of incident DM associated with heart failure, with the strength of the association proportionate to the severity of heart failure [20]. The same study reported that mild, moderate and severe heart failure was associated with $34 \%, 63 \%$, and $68 \%$ increased risk of incident DM, respectively. Findings from other studies also concur with the results of the current study, showing that CVD significantly increases the risk of incident DM [6, 21].

Several mediators in the pathway between self-reported CVD and incident DM were examined in this study. Our results showed that the observed association between self-reported CVD and incident DM was partly attributed to medications used in the management of CVD. Beta-blockers, statins, and diuretics accounted for $31 \%, 24 \%$, and $8 \%$ of the association between self-reported CVD and incident DM, respectively. We also noted that weight gain did not explain the association between self-reported CVD and incident DM. These findings are important as beta-blockers, diuretics, and statins remain among the most commonly used medication classes for treating CVD.

The mediating effects of beta-blockers, statins, and diuretics on incident DM are consistent with previous studies reporting a significantly greater risk of DM with these pharmacological agents. Previous studies have linked new-onset DM to the use of $\beta$ blockers [7] and diuretics [8]. A 3- to 6-year follow-up study has reported a $28 \%$ increased risk for incident DM among individuals receiving $\beta$-blocker therapy [7]. A meta-analysis has found that atenolol and metoprolol are associated with a $30 \%$ and $32 \%$ increased risk for incident DM, respectively [22]. Diuretics were found to increase the risk of incident DM by $23 \%$ [8]. Statin-based therapy was associated with a $9 \%$ increased risk of incident DM in pooled data from 13 trials [23]. Other studies found no association between beta-blockers [8], diuretics [7], and statins [24] and subsequent development of DM. The lack of association observed in those studies may be explained by the type of study designs, the type of beta-blocker used, dosages, and duration of follow-up. The results of this study also showed that the use of beta-blockers was a stronger mediator for incident DM than the use of statins and diuretics. This is consistent with prior research reporting that the association between 
beta-blockers and incident DM is greater than that for other antihypertensive agents [7]. We found that the mediating effect of statins appears greater than that of diuretics. A previous study examining the diabetogenic effects of statins and diuretics has found a stronger effect of statins than diuretics [8].

The mediating effect of beta-blockers on incident DM is biologically plausible. Insulin release from the pancreas is regulated by the autonomic nervous system [25]. Thus, pharmacological agents that affect this system can impact insulin secretion. Beta-blockers can potentially inhibit $\beta-2$ receptors involved in regulation of pancreatic autonomic pathways, thus attenuating insulin release from the pancreas. Studies have reported that propranolol infusion caused decrease in insulin secretion [26, 27]. Beta-blockers have also been reported to decrease insulin sensitivity [28]. The mechanisms underlying the increased risk of DM associated with the use of statins and diuretics are not fully understood. Hypotheses for statin-induced DM have focused on statin-induced insulin resistance, inhibition of insulin secretion and synthesis, and decreased insulin-mediated cellular glucose uptake $[29,30]$. The mechanism for diuretics-induced DM has been postulated to result from diuretics-induced hypokalemia leading to decreased insulin secretion and/or decreased insulin sensitivity [31, 32]. However, a study has reported no association between diuretics-induced change in potassium and blood glucose [33].

This study has several limitations. Data were not available on doses of drugs, medication adherence, and the duration of treatment. Due to the relatively small numbers of cardiovascular drug users in the matched cohort, we did not examine differences between specific types of beta-blockers and diuretics (e.g., cardio-selective vs. nonselective beta-blockers, thiazides vs. other diuretics). The present study might also be subject to self-report bias because CVD was self-reported, but the association remained when major ECG abnormalities were used to define CVD. The results of this study might be due to residual confounding related to unmeasured or hidden covariates. It is unlikely that a hidden covariate related to both CVD and DM could exist and be completely unrelated to any of the covariates used in our PS model. Furthermore, such confounding is unlikely to explain our results given that beta-blockers, statins, and diuretics have generally been thought to increase the risk of DM. Inadequate matching might also affect the findings of this study; however, individuals with and without selfreported CVD in our analytic sample were nearly identical with a mean PS difference of $0.4 \%$ in absolute value. While the exclusion of unmatched individuals might have compromised to some degree the external validity of the results presented in this study, we believe that our matching procedure improves internal validity.

Notwithstanding these limitations, the findings from this study add to the growing concern that beta-blockers, statins, and diuretics may be diabetogenic. These drugs are recommended for secondary prevention of CVD because of their proven benefits. The increased risk of DM associated with the use of these drugs should not discourage clinicians from prescribing them, but rather, should be weighed against their proven cardiovascular benefits.

Our results suggest that the excess risk of on incident DM associated with self-reported CVD was not completely explained by the three potential mediators identified in our analysis. Thus, the results highlight the need for investigation of other factors that might account for the unexplained risk. Furthermore, additional studies are needed to more fully understand the mechanisms by which beta-blockers, diuretics, and statins increase DM risk.

\section{Conclusions}

Using data from the Hispanic Community Health Study/Study of Latinos (HCHS/SOL), we found that the association between cardiovascular disease and incident diabetes mellitus was partly attributed to beta-blockers, statins, and diuretics. The current study suggests that further research is needed to examine the risk benefit ratio of using these medications for their known cardiovascular benefit versus the potential risk for incident diabetes.

\section{Declarations}

ACKNOWLEDGEMENTS - We would like to thank the staff and participants of HCHS/SOL for their important contributions. We would also like to thank the HCHS/SOL Publications Committee for reviewing our manuscript for scientific content and consistency of data interpretation with previous HCHS/SOL publications. Celestin Missikpode was supported by the National Heart, Lung, and Blood Institute (NHLBI)(T32-HL125294). The Hispanic Community Health Study/Study of Latinos was carried out as a collaborative study supported by contracts from the National Heart, Lung, and Blood Institute (NHLBI) to the University of North Carolina (N01-HC65233), University of Miami (N01-HC65234), Albert Einstein College of Medicine (N01-HC65235), Northwestern University (N01-HC65236), and San Diego State University (N01-HC65237). The following Institutes/Centers/Offices contribute to the HCHS/SOL through a transfer of funds to the NHLBI: National Institute on Minority Health and Health Disparities, National Institute on Deafness and Other Communication Disorders, National Institute of Dental and Craniofacial Research, National Institute of Diabetes and Digestive and Kidney Diseases, National Institute of Neurological Disorders and Stroke, NIH Institution-Office of Dietary Supplements. 
Disclosures: Krista M Perreira is a co-investigator on the HCHS/SOL grant from NHLBI.

\section{References}

1. Amos, A. F., McCarty, D. J., \& Zimmet, P. (1997). The rising global burden of diabetes and its complications: estimates and projections to the year 2010. Diabetic medicine, 14(S5), S7-S85.

2. King, H., Aubert, R. E., \& Herman, W. H. (1998). Global burden of diabetes, 1995-2025: prevalence, numerical estimates, and projections. Diabetes care, 21(9), 1414-1431.

3. Like, Y. M. A. National diabetes statistics report, 2017: estimates of diabetes and its burden in the United States.

4. Honeycutt, A. A., Boyle, J. P., Broglio, K. R., Thompson, T. J., Hoerger, T. J., Geiss, L. S., \& Narayan, K. V. (2003). A dynamic Markov model for forecasting diabetes prevalence in the United States through 2050. Health care management science, 6(3), $155-164$.

5. Nichols, G. A., \& Moler, E. J. (2011). Cardiovascular disease, heart failure, chronic kidney disease and depression independently increase the risk of incident diabetes. Diabetologia, 54(3), 523-526.

6. Guglin, M., Lynch, K., \& Krischer, J. (2014). Heart failure as a risk factor for diabetes mellitus. Cardiology, 129(2), 84-92.

7. Gress, T. W., Nieto, F. J., Shahar, E., Wofford, M. R., \& Brancati, F. L. (2000). Hypertension and antihypertensive therapy as risk factors for type 2 diabetes mellitus. New England Journal of Medicine, 342(13), 905-912.

8. Shen, L., Shah, B. R., Reyes, E. M., Thomas, L., Wojdyla, D., Diem, P., ... \& Haffner, S. M. (2013). Role of diuretics, $\beta$ blockers, and statins in increasing the risk of diabetes in patients with impaired glucose tolerance: reanalysis of data from the NAVIGATOR study. Bmj, 347, f6745.

9. Culver, A. L., Ockene, I. S., Balasubramanian, R., Olendzki, B. C., Sepavich, D. M., Wactawski-Wende, J., ... \& Rahilly-Tierny, C. (2012). Statin use and risk of diabetes mellitus in postmenopausal women in the Women's Health Initiative. Archives of internal medicine, 172(2), 144-152.

10. Jehn, M., Schmidt-Trucksäss, A., Schuster, T., Weis, M., Hanssen, H., Halle, M., \& Koehler, F. (2009). Daily walking performance as an independent predictor of advanced heart failure: prediction of exercise capacity in chronic heart failure. American heart journal, 157(2), 292-298.

11. Lopez-Jimenez, F., Jacobsen, S. J., Reeder, G. S., Weston, S. A., Meverden, R. A., \& Roger, V. L. (2004). Prevalence and secular trends of excess body weight and impact on outcomes after myocardial infarction in the community. Chest, 125(4), 1205-1212.

12. Sorlie, P. D., Avilés-Santa, L. M., Wassertheil-Smoller, S., Kaplan, R. C., Daviglus, M. L., Giachello, A. L., ... \& LaVange, L. (2010). Design and implementation of the Hispanic community health study/study of Latinos. Annals of epidemiology, 20(8), 629-641.

13. American Diabetes Association. (2016). 2. Classification and diagnosis of diabetes. Diabetes care, 39(Supplement 1), S13-S22.

14. Normand, S. L. T., Landrum, M. B., Guadagnoli, E., Ayanian, J. Z., Ryan, T. J., Cleary, P. D., \& McNeil, B. J. (2001). Validating recommendations for coronary angiography following acute myocardial infarction in the elderly: a matched analysis using propensity scores. Journal of clinical epidemiology, 54(4), 387-398.

15. Parsons, L. S. (2004, May). Performing a 1: N case-control match on propensity score. In Proceedings of the 29th Annual SAS users group international conference (pp. 165-29). SAS Institute. https://support.sas.com/resources/papers/proceedings/proceedings/sugi29/165-29.pdf

16. Tchetgen, E. J., \& Shpitser, I. (2012). Semiparametric Theory for Causal Mediation Analysis: efficiency bounds, multiple robustness, and sensitivity analysis. Annals of statistics, 40(3), 1816-1845. doi:10.1214/12-AOS990

17. Tchetgen, E. J. T., \& Phiri, K. (2017). Evaluation of medication-mediated effects in pharmacoepidemiology. Epidemiology (Cambridge, Mass.), 28(3), 439.

18. Rubin, D. B. (2001). Using propensity scores to help design observational studies: application to the tobacco litigation. Health Services and Outcomes Research Methodology, 2(3-4), 169-188.

19. Dehejia, R. H., \& Wahba, S. (1999). Causal effects in nonexperimental studies: Reevaluating the evaluation of training programs. Journal of the American statistical Association, 94(448), 1053-1062.

20. Andersson, C., Norgaard, M. L., Hansen, P. R., Fosbøl, E. L., Schmiegelow, M., Weeke, P., ... \& Køber, L. (2010). Heart failure severity, as determined by loop diuretic dosages, predicts the risk of developing diabetes after myocardial infarction: a nationwide cohort study. European journal of heart failure, 12(12), 1333-1338.

21. Modin, D., Møgelvang, R., Jørgensen, P. G., Jensen, M. T., Seferovic, J. P., \& Biering-Sørensen, T. (2019). Left ventricular concentric geometry predicts incident diabetes mellitus independent of established risk factors in the general population: the Copenhagen City Heart Study. Cardiovascular diabetology, 18(1), 37. 
22. Bangalore, S., Parkar, S., Grossman, E., \& Messerli, F. H. (2007). A meta-analysis of 94,492 patients with hypertension treated with beta blockers to determine the risk of new-onset diabetes mellitus. The American journal of cardiology, 100(8), 1254-1262.

23. Sattar, N., Preiss, D., Murray, H. M., Welsh, P., Buckley, B. M., de Craen, A. J., ... \& Macfarlane, P. W. (2010). Statins and risk of incident diabetes: a collaborative meta-analysis of randomised statin trials. The Lancet, 375(9716), 735-742.

24. Yusuf, S., Bosch, J., Dagenais, G., Zhu, J., Xavier, D., Liu, L., ... \& Avezum, A. (2016). Cholesterol lowering in intermediate-risk persons without cardiovascular disease. New England Journal of Medicine, 374(21), 2021-2031.

25. Kirchgessner, A. L., \& Gershon, M. D. (1990). Innervation of the pancreas by neurons in the gut. Journal of Neuroscience, 10(5), 16261642.

26. Cerasi, E., Luft, R., \& Efendić, S. (1972). Effect of adrenergic blocking agents on insulin response to glucose infusion in man. Acta endocrinologica, 69(2), 335-346.

27. Robertson, R. P., \& Porte, D. (1973). Adrenergic modulation of basal insulin secretion in man. Diabetes, 22(1), 1-8.

28. Lithell, H., Pollare, T., \& Vessby, B. (1992). Metabolic effects of pindolol and propranolol in a double-blind cross-over study in hypertensive patients. Blood Pressure, 1(2), 92-101.

29. Ganda, O. P. (2016). Statin-induced diabetes: incidence, mechanisms, and implications. F1000Research, 5.

30. Nakata, M., Nagasaka, S., Kusaka, I., Matsuoka, H., Ishibashi, S., \& Yada, T. (2006). Effects of statins on the adipocyte maturation and expression of glucose transporter 4 (SLC2A4): implications in glycaemic control. Diabetologia, 49(8), 1881-1892.

31. Carter, B. L., Einhorn, P. T., Brands, M., He, J., Cutler, J. A., Whelton, P. K., ... \& Wright Jr, J. T. (2008). Thiazide-induced dysglycemia: call for research from a working group from the national heart, lung, and blood institute. Hypertension, 52(1), 30-36.

32. Shafi, T., Appel, L. J., Miller III, E. R., Klag, M. J., \& Parekh, R. S. (2008). Changes in serum potassium mediate thiazide-induced diabetes. Hypertension, 52(6), 1022-1029.

33. Smith, S. M., Anderson, S. D., Wen, S., Gong, Y., Turner, S. T., Cooper-DeHoff, R. M., ... \& Feng, H. (2009). Lack of correlation between thiazide-induced hyperglycemia and hypokalemia: subgroup analysis of results from the pharmacogenomic evaluation of antihypertensive responses (PEAR) study. Pharmacotherapy: The Journal of Human Pharmacology and Drug Therapy, 29(10), 11571165.

\section{Tables}

Table 1: Covariate balance check at baseline - Before and after propensity score matching among HCHS/SOL participants without diabetes at baseline (Visit 1) 


\begin{tabular}{|c|c|c|c|c|c|c|c|c|c|}
\hline \multirow{4}{*}{ Categorical covariates } & \multirow{2}{*}{\multicolumn{2}{|c|}{$\begin{array}{l}\text { Before matching } \\
\text { Self-reported CVD }\end{array}$}} & \multirow{4}{*}{$\begin{array}{l}\mathrm{P}- \\
\text { value }\end{array}$} & \multicolumn{5}{|c|}{ After matching } & \multirow{4}{*}{$\begin{array}{l}\text { P- } \\
\text { value }\end{array}$} \\
\hline & & & & \multicolumn{2}{|c|}{ Self-reported CVD } & \multirow{3}{*}{$\begin{array}{l}\mathrm{P}- \\
\text { value }\end{array}$} & \multicolumn{2}{|c|}{ ECG-defined CVD } & \\
\hline & $\begin{array}{l}\text { Yes } \\
(\mathrm{N}=2179)\end{array}$ & $\begin{array}{l}\mathrm{No} \\
(\mathrm{N}=6498)\end{array}$ & & \multirow{2}{*}{$\begin{array}{l}\text { Yes } \\
(\mathrm{N}=2081) \\
N(\%)\end{array}$} & $\begin{array}{l}\text { No } \\
(\mathrm{N}=2081)\end{array}$ & & $\begin{array}{l}\text { Yes } \\
(N=591)\end{array}$ & & \\
\hline & $\mathrm{N}(\%)$ & $\mathrm{N}(\%)$ & & & \multirow[t]{2}{*}{$N(\%)$} & & \multirow[t]{2}{*}{$\mathrm{N}(\%)$} & $(\mathrm{IN}-391)$ & \\
\hline & & & & & & & & & \\
\hline Study site & & & $<.0001$ & & & 0.1630 & & & 0.3286 \\
\hline Bronx & $\begin{array}{l}665 \\
(30.5)\end{array}$ & $\begin{array}{l}1190 \\
(18.3)\end{array}$ & & $\begin{array}{l}603 \\
(29.0)\end{array}$ & $\begin{array}{l}560 \\
(26.9)\end{array}$ & & $\begin{array}{l}220 \\
(37.2)\end{array}$ & $\begin{array}{l}220 \\
(37.2)\end{array}$ & \\
\hline Chicago & $\begin{array}{l}488 \\
(22.4)\end{array}$ & $\begin{array}{l}1797 \\
(27.7)\end{array}$ & & $\begin{array}{l}472 \\
(22.7)\end{array}$ & $\begin{array}{l}526 \\
(25.3)\end{array}$ & & $\begin{array}{l}121 \\
(20.5)\end{array}$ & $\begin{array}{l}141 \\
(23.9)\end{array}$ & \\
\hline Miami & $\begin{array}{l}514 \\
(23.6)\end{array}$ & $\begin{array}{l}1728 \\
(26.6)\end{array}$ & & $\begin{array}{l}502 \\
(24.1)\end{array}$ & $\begin{array}{l}480 \\
(23.1)\end{array}$ & & $\begin{array}{l}146 \\
(24.7)\end{array}$ & $\begin{array}{l}145 \\
(24.5)\end{array}$ & \\
\hline San Diego & $\begin{array}{l}512 \\
(23.5)\end{array}$ & $\begin{array}{l}1783 \\
(27.4)\end{array}$ & & $\begin{array}{l}504 \\
(24.2)\end{array}$ & $\begin{array}{l}515 \\
(24.7)\end{array}$ & & $\begin{array}{l}104 \\
(17.6)\end{array}$ & $\begin{array}{l}85 \\
(14.4)\end{array}$ & \\
\hline Sex (Male) & $\begin{array}{l}689 \\
(31.6)\end{array}$ & $\begin{array}{l}2483 \\
(38.2)\end{array}$ & $<.0001$ & $\begin{array}{l}669 \\
(32.2)\end{array}$ & $\begin{array}{l}744 \\
(35.7)\end{array}$ & 0.0141 & $\begin{array}{l}260 \\
(44.0)\end{array}$ & $\begin{array}{l}255 \\
(43.2)\end{array}$ & 0.7693 \\
\hline Hispanic/Latino Background & & & $<.0001$ & & & 0.4727 & & & 0.8858 \\
\hline Dominican & $\begin{array}{l}256 \\
(11.8)\end{array}$ & $499(7.7)$ & & $\begin{array}{l}239 \\
(11.5)\end{array}$ & $\begin{array}{l}239 \\
(11.5)\end{array}$ & & $\begin{array}{l}82 \\
(13.9)\end{array}$ & $\begin{array}{l}89 \\
(15.1)\end{array}$ & \\
\hline Central American & $208(9.5)$ & $\begin{array}{l}728 \\
(11.2)\end{array}$ & & $204(9.8)$ & $\begin{array}{l}229 \\
(11.0)\end{array}$ & & $\begin{array}{l}69 \\
(11.7)\end{array}$ & $\begin{array}{l}64 \\
(10.8)\end{array}$ & \\
\hline Cuban & $\begin{array}{l}325 \\
(14.9)\end{array}$ & $\begin{array}{l}955 \\
(14.7)\end{array}$ & & $\begin{array}{l}315 \\
(15.1)\end{array}$ & $\begin{array}{l}283 \\
(13.6)\end{array}$ & & $\begin{array}{l}91 \\
(15.4)\end{array}$ & $\begin{array}{l}81 \\
(13.7)\end{array}$ & \\
\hline Mexican & $\begin{array}{l}724 \\
(33.2)\end{array}$ & $\begin{array}{l}2883 \\
(44.4)\end{array}$ & & $\begin{array}{l}714 \\
(34.3)\end{array}$ & $\begin{array}{l}732 \\
(35.2)\end{array}$ & & $\begin{array}{l}177 \\
(29.9)\end{array}$ & $\begin{array}{l}167 \\
(28.3)\end{array}$ & \\
\hline Puerto Rican & $\begin{array}{l}471 \\
(21.6)\end{array}$ & $\begin{array}{l}742 \\
(11.4)\end{array}$ & & $\begin{array}{l}420 \\
(20.2)\end{array}$ & $\begin{array}{l}389 \\
(18.7)\end{array}$ & & $\begin{array}{l}123 \\
(20.8)\end{array}$ & $\begin{array}{l}136 \\
(23.0)\end{array}$ & \\
\hline South American & $147(6.8)$ & $495(7.6)$ & & $141(6.8)$ & $156(7.5)$ & & $34(5.8)$ & $39(6.6)$ & \\
\hline $\begin{array}{l}\text { More than one/Other } \\
\text { heritage }\end{array}$ & $48(2.2)$ & $196(3.0)$ & & $48(2.3)$ & $53(2.5)$ & & $15(2.5)$ & $15(2.5)$ & \\
\hline Marital status & & & $<.0001$ & & & 0.3221 & & & 0.4718 \\
\hline Single & $\begin{array}{l}470 \\
(21.6)\end{array}$ & $\begin{array}{l}1810 \\
(27.9)\end{array}$ & & $\begin{array}{l}449 \\
(21.6)\end{array}$ & $\begin{array}{l}433 \\
(20.8)\end{array}$ & & $\begin{array}{l}146 \\
(24.7)\end{array}$ & $\begin{array}{l}151 \\
(25.5)\end{array}$ & \\
\hline $\begin{array}{l}\text { Married or living with a } \\
\text { partner }\end{array}$ & $\begin{array}{l}1067 \\
(49.0)\end{array}$ & $\begin{array}{l}3635 \\
(55.9)\end{array}$ & & $\begin{array}{l}1047 \\
(50.3)\end{array}$ & $\begin{array}{l}1095 \\
(52.6)\end{array}$ & & $\begin{array}{l}296 \\
(50.1)\end{array}$ & $\begin{array}{l}276 \\
(46.7)\end{array}$ & \\
\hline Separated/divorced/widow(er) & $\begin{array}{l}642 \\
(29.4)\end{array}$ & $\begin{array}{l}1053 \\
(16.2)\end{array}$ & & $\begin{array}{l}585 \\
(28.1)\end{array}$ & $\begin{array}{l}553 \\
(26.6)\end{array}$ & & $\begin{array}{l}149 \\
(25.2)\end{array}$ & $\begin{array}{l}164 \\
(27.8)\end{array}$ & \\
\hline Educational attainment & & & $<.0001$ & & & 0.4174 & & & 0.8320 \\
\hline Less than high school/GED & $\begin{array}{l}933 \\
(42.8)\end{array}$ & $\begin{array}{l}2071 \\
(31.9)\end{array}$ & & $\begin{array}{l}870 \\
(41.8)\end{array}$ & $\begin{array}{l}831 \\
(39.9)\end{array}$ & & $\begin{array}{l}223 \\
(37.7)\end{array}$ & $\begin{array}{l}223 \\
(37.7)\end{array}$ & \\
\hline High school diploma/GED & $\begin{array}{l}456 \\
(20.9)\end{array}$ & $\begin{array}{l}1807 \\
(27.8)\end{array}$ & & $\begin{array}{l}441 \\
(21.2)\end{array}$ & $\begin{array}{l}467 \\
(22.4)\end{array}$ & & $\begin{array}{l}145 \\
(24.5)\end{array}$ & $\begin{array}{l}137 \\
(23.2)\end{array}$ & \\
\hline $\begin{array}{l}\text { Greater than high } \\
\text { school/GED }\end{array}$ & $\begin{array}{l}790 \\
(36.3)\end{array}$ & $\begin{array}{l}2620 \\
(40.3)\end{array}$ & & $\begin{array}{l}770 \\
(37.0)\end{array}$ & $\begin{array}{l}783 \\
(37.6)\end{array}$ & & $\begin{array}{l}223 \\
(37.8)\end{array}$ & $\begin{array}{l}231 \\
(39.1)\end{array}$ & \\
\hline Having health Insurance & $\begin{array}{l}1256 \\
(57.6)\end{array}$ & $\begin{array}{l}2948 \\
(45.4)\end{array}$ & $<.0001$ & $\begin{array}{l}1166 \\
(56.0)\end{array}$ & $\begin{array}{l}1178 \\
(56.6)\end{array}$ & 0.7076 & $\begin{array}{l}356 \\
(60.2)\end{array}$ & $\begin{array}{l}366 \\
(61.9)\end{array}$ & 0.5508 \\
\hline Cigarette use & & & $<.0001$ & & & 0.3582 & & & 0.3489 \\
\hline Never & $\begin{array}{l}1279 \\
(58.7)\end{array}$ & $\begin{array}{l}4313 \\
(66.4)\end{array}$ & & $\begin{array}{l}1233 \\
(59.3)\end{array}$ & $\begin{array}{l}1232 \\
(59.2)\end{array}$ & & $\begin{array}{l}350 \\
(59.2)\end{array}$ & $\begin{array}{l}336 \\
(56.9)\end{array}$ & \\
\hline
\end{tabular}

Page 9/14 


\begin{tabular}{|c|c|c|c|c|c|c|c|c|c|}
\hline Former & $\begin{array}{l}457 \\
(21.0)\end{array}$ & $\begin{array}{l}1066 \\
(16.4)\end{array}$ & & $\begin{array}{l}429 \\
(20.6)\end{array}$ & $\begin{array}{l}459 \\
(22.1)\end{array}$ & & $\begin{array}{l}109 \\
(18.4)\end{array}$ & $\begin{array}{l}129 \\
(21.8)\end{array}$ & \\
\hline Current & $\begin{array}{l}443 \\
(20.3)\end{array}$ & $\begin{array}{l}1119 \\
(17.2)\end{array}$ & & $\begin{array}{l}419 \\
(20.1)\end{array}$ & $\begin{array}{l}390 \\
(18.7)\end{array}$ & & $\begin{array}{l}132 \\
(22.4)\end{array}$ & $\begin{array}{l}126 \\
(21.3)\end{array}$ & \\
\hline Alcohol use & & & $<.0001$ & & & 0.2738 & & & 0.4559 \\
\hline Never & $\begin{array}{l}422 \\
(19.4)\end{array}$ & $\begin{array}{l}1316 \\
(20.2)\end{array}$ & & $\begin{array}{l}408 \\
(19.6)\end{array}$ & $\begin{array}{l}372 \\
(17.9)\end{array}$ & & $\begin{array}{l}108 \\
(18.3)\end{array}$ & $\begin{array}{l}125 \\
(21.1))\end{array}$ & \\
\hline Former & $\begin{array}{l}772 \\
(35.4)\end{array}$ & $\begin{array}{l}1934 \\
(29.8)\end{array}$ & & $\begin{array}{l}718 \\
(34.5)\end{array}$ & $\begin{array}{l}712 \\
(34.2)\end{array}$ & & $\begin{array}{l}188 \\
(31.8)\end{array}$ & $\begin{array}{l}179 \\
(30.3)\end{array}$ & \\
\hline Current & $\begin{array}{l}985 \\
(45.2)\end{array}$ & $\begin{array}{l}3248 \\
(50.0)\end{array}$ & & $\begin{array}{l}955 \\
(45.9)\end{array}$ & $\begin{array}{l}997 \\
(47.9)\end{array}$ & & $\begin{array}{l}295 \\
(49.9)\end{array}$ & $\begin{array}{l}287 \\
(48.6)\end{array}$ & \\
\hline Physical activity level & & & $<.0001$ & & & 0.3529 & & & 0.2922 \\
\hline Low & $197(9.0)$ & $\begin{array}{l}695 \\
(10.7)\end{array}$ & & $195(9.4)$ & $207(9.9)$ & & $53(9.0)$ & $40(6.8)$ & \\
\hline Moderate & $\begin{array}{l}921 \\
(42.3)\end{array}$ & $\begin{array}{l}3013 \\
(46.4)\end{array}$ & & $\begin{array}{l}891 \\
(42.8)\end{array}$ & $\begin{array}{l}925 \\
(44.5)\end{array}$ & & $\begin{array}{l}262 \\
(44.3)\end{array}$ & $\begin{array}{l}280 \\
(47.4)\end{array}$ & \\
\hline High & $\begin{array}{l}1061 \\
(48.7)\end{array}$ & $\begin{array}{l}2790 \\
(42.9)\end{array}$ & & $\begin{array}{l}995 \\
(47.8)\end{array}$ & $\begin{array}{l}949 \\
(45.6)\end{array}$ & & $\begin{array}{l}276 \\
(46.7)\end{array}$ & $\begin{array}{l}271 \\
(45.8)\end{array}$ & \\
\hline CKD & & & $<.0001$ & & & 0.7714 & & & 0.6535 \\
\hline Normal & $\begin{array}{l}824 \\
(37.8)\end{array}$ & $\begin{array}{l}3427 \\
(52.7)\end{array}$ & & $\begin{array}{l}804 \\
(38.6)\end{array}$ & $\begin{array}{l}809 \\
(38.9)\end{array}$ & & $\begin{array}{l}233 \\
(39.4)\end{array}$ & $\begin{array}{l}247 \\
(41.8)\end{array}$ & \\
\hline Mild/Moderate & $\begin{array}{l}1350 \\
(62.0)\end{array}$ & $\begin{array}{l}3064 \\
(47.2)\end{array}$ & & $\begin{array}{l}1272 \\
(61.1)\end{array}$ & $\begin{array}{l}1269 \\
(61.0)\end{array}$ & & $\begin{array}{l}355 \\
(60.1)\end{array}$ & $\begin{array}{l}342 \\
(57.9)\end{array}$ & \\
\hline Severe/End-Stage & $5(0.2)$ & $7(0.1)$ & & $5(0.3)$ & $3(0.1)$ & & $3(0.5)$ & $2(0.3)$ & \\
\hline Gestational diabetes & $35(1.6)$ & $113(1.7)$ & 0.6788 & $34(1.6)$ & $41(1.9)$ & 0.4147 & $10(1.7)$ & $8(1.4)$ & 0.6348 \\
\hline Family history of diabetes & $\begin{array}{l}1021 \\
(46.9)\end{array}$ & $\begin{array}{l}2591 \\
(39.9)\end{array}$ & $<.0001$ & $\begin{array}{l}961 \\
(46.2)\end{array}$ & $\begin{array}{l}919 \\
(44.2)\end{array}$ & 0.1908 & $\begin{array}{l}254 \\
(43.0)\end{array}$ & $\begin{array}{l}239 \\
(40.4)\end{array}$ & 0.3762 \\
\hline Metabolic syndrome & $\begin{array}{l}796 \\
(36.5)\end{array}$ & $\begin{array}{l}1709 \\
(26.3)\end{array}$ & $<.0001$ & $\begin{array}{l}764 \\
(36.7)\end{array}$ & $\begin{array}{l}751 \\
(36.1)\end{array}$ & 0.6754 & $\begin{array}{l}237 \\
(40.1)\end{array}$ & $\begin{array}{l}210 \\
(35.5)\end{array}$ & 0.1053 \\
\hline Hypertension & $\begin{array}{l}754 \\
(34.6)\end{array}$ & $\begin{array}{l}1110 \\
(17.1)\end{array}$ & $<.0001$ & $\begin{array}{l}685 \\
(32.9)\end{array}$ & $\begin{array}{l}679 \\
(32.6)\end{array}$ & 0.8429 & $\begin{array}{l}237 \\
(40.1)\end{array}$ & $\begin{array}{l}225 \\
(38.1)\end{array}$ & 0.4744 \\
\hline High total cholesterol & $\begin{array}{l}996 \\
(45.7)\end{array}$ & $\begin{array}{l}2521 \\
(38.8)\end{array}$ & $<.0001$ & $\begin{array}{l}939 \\
(45.1)\end{array}$ & $\begin{array}{l}928 \\
(44.6)\end{array}$ & 0.7317 & $\begin{array}{l}298 \\
(50.4)\end{array}$ & $\begin{array}{l}271 \\
(45.9)\end{array}$ & 0.1160 \\
\hline Prediabetes & $\begin{array}{l}1347 \\
(61.8)\end{array}$ & $\begin{array}{l}3026 \\
(46.6)\end{array}$ & $<.0001$ & $\begin{array}{l}1263 \\
(60.7)\end{array}$ & $\begin{array}{l}1272 \\
(61.1)\end{array}$ & 0.7750 & $\begin{array}{l}356 \\
(60.2)\end{array}$ & $\begin{array}{l}337 \\
(57.0)\end{array}$ & 0.2618 \\
\hline BMI categories & & & $<.0001$ & & & 0.1049 & & & 0.2475 \\
\hline Underweight $(\mathrm{BMI}<18.5)$ & $16(0.7)$ & $50(0.8)$ & & $11(0.5)$ & $13(0.6)$ & & $5(0.9)$ & $4(0.7)$ & \\
\hline Normal $(18.5 \leq \mathrm{BMI}<25)$ & $\begin{array}{l}367 \\
(16.8)\end{array}$ & $\begin{array}{l}1413 \\
(21.8)\end{array}$ & & $\begin{array}{l}357 \\
(17.2)\end{array}$ & $\begin{array}{l}426 \\
(20.5)\end{array}$ & & $\begin{array}{l}102 \\
(17.3)\end{array}$ & $\begin{array}{l}122 \\
(20.6)\end{array}$ & \\
\hline 30) Overweight $(25 \leq \mathrm{BMI}<$ & $\begin{array}{l}820 \\
(37.6)\end{array}$ & $\begin{array}{l}2635 \\
(40.6)\end{array}$ & & $\begin{array}{l}800 \\
(38.4)\end{array}$ & $\begin{array}{l}781 \\
(37.5)\end{array}$ & & $\begin{array}{l}207 \\
(35.0)\end{array}$ & $\begin{array}{l}227 \\
(38.4)\end{array}$ & \\
\hline Obese I $(30 \leq \mathrm{BMI}<35)$ & $\begin{array}{l}585 \\
(26.9)\end{array}$ & $\begin{array}{l}1598 \\
(24.6)\end{array}$ & & $\begin{array}{l}558 \\
(26.8)\end{array}$ & $\begin{array}{l}547 \\
(26.3)\end{array}$ & & $\begin{array}{l}172 \\
(29.1)\end{array}$ & $\begin{array}{l}144 \\
(24.4)\end{array}$ & \\
\hline Obese II $(35 \leq \mathrm{BMI}<40)$ & $\begin{array}{l}272 \\
(12.5)\end{array}$ & $529(8.1)$ & & $\begin{array}{l}243 \\
(11.7)\end{array}$ & $\begin{array}{l}216 \\
(10.4)\end{array}$ & & $\begin{array}{l}70 \\
(11.8)\end{array}$ & $\begin{array}{l}68 \\
(11.5)\end{array}$ & \\
\hline Obese III (BMI $\geq 40)$ & $119(5.5)$ & $273(4.2)$ & & $112(5.4)$ & $98(4.7)$ & & $35(5.9)$ & $26(4.4)$ & \\
\hline Continuous covariates & $\begin{array}{l}\text { Mean } \\
\text { (SE) }\end{array}$ & $\begin{array}{l}\text { Mean } \\
\text { (SE) }\end{array}$ & $\begin{array}{l}\text { P- } \\
\text { value }\end{array}$ & $\begin{array}{l}\text { Mean } \\
\text { (SE) }\end{array}$ & $\begin{array}{l}\text { Mean } \\
\text { (SE) }\end{array}$ & $\begin{array}{l}\mathrm{P}- \\
\text { value }\end{array}$ & $\begin{array}{l}\text { Mean } \\
\text { (SE) }\end{array}$ & $\begin{array}{l}\text { Mean } \\
\text { (SE) }\end{array}$ & $\begin{array}{l}\mathrm{P}- \\
\text { value }\end{array}$ \\
\hline
\end{tabular}




\begin{tabular}{|c|c|c|c|c|c|c|c|c|c|}
\hline Age & $\begin{array}{l}52.7 \\
(10.3)\end{array}$ & $\begin{array}{l}42.9 \\
(13.1)\end{array}$ & $<.0001$ & $\begin{array}{l}52.1 \\
(10.2)\end{array}$ & $\begin{array}{l}52.0 \\
(11.0)\end{array}$ & 0.6496 & $\begin{array}{l}50.8 \\
(13.0)\end{array}$ & $\begin{array}{l}49.3 \\
(13.3)\end{array}$ & 0.0594 \\
\hline Cigarette Pack Years & $\begin{array}{l}7.1 \\
(15.3)\end{array}$ & $\begin{array}{l}4.0 \\
(10.8)\end{array}$ & $<.0001$ & $\begin{array}{l}6.6 \\
(14.1)\end{array}$ & $\begin{array}{l}6.8 \\
(15.0)\end{array}$ & 0.6318 & $\begin{array}{l}6.9 \\
(15.0)\end{array}$ & $\begin{array}{l}8.0 \\
(15.7)\end{array}$ & 0.2188 \\
\hline Diet quality index (AHEI2010) & $\begin{array}{l}49.5 \\
(7.5)\end{array}$ & $\begin{array}{l}48.9 \\
(7.5)\end{array}$ & 0.0010 & $\begin{array}{l}49.6 \\
(7.5)\end{array}$ & $\begin{array}{l}49.9 \\
(7.6)\end{array}$ & 0.1581 & $\begin{array}{l}49.2 \\
(7.6)\end{array}$ & $\begin{array}{l}48.3 \\
(7.3)\end{array}$ & 0.0434 \\
\hline \multicolumn{10}{|l|}{ Outcome at Visit 2} \\
\hline Incident diabetes, N (\%) & $\begin{array}{l}345 \\
(15.8)\end{array}$ & $644(9.9)$ & $<.0001$ & $\begin{array}{l}325 \\
(15.6)\end{array}$ & $\begin{array}{l}265 \\
(12.7)\end{array}$ & 0.0077 & $\begin{array}{l}101 \\
(17.1)\end{array}$ & $\begin{array}{l}75 \\
(12.7)\end{array}$ & 0.0336 \\
\hline
\end{tabular}

Footnote: ECG findings included major Q Wave abnormalities (old Myocardial Infarction); minor Q, QS waves with ST, T abnormalities (possible old Myocardial Infarction); major Isolated ST, T abnormalities; Left Ventricular Hypertrophy; Atrial Fibrillation or Flutter; complete (third degree) A-V block; Wolff-Parkinson-White pattern; major QT Prolongation, QTi $\geq 116 \%$; pacemaker; supraventricular tachycardia intermittent.

Table 2: Distribution of self-reported cardiovascular disease and incident diabetes by medication use at baseline (Visit 1 ) in the matched cohort ( $\mathrm{N}=4162)$

\begin{tabular}{|cllllll|}
\hline \multicolumn{5}{|l}{ Self-reported CVD at Visit 1 (baseline) } & \multicolumn{4}{l|}{ Incident diabetes at Visit 2 (Follow-up) } \\
\hline Medications & Yes & No & P-value & Yes & No & P-value \\
& N (\%) & N (\%) & & N (\%) & N (\%) & \\
\hline Beta-blocker use & & & $<.0001$ & & & $<.0001$ \\
\hline Yes & $235(66.2)$ & $120(33.8)$ & & $85(23.9)$ & $270(76.1)$ & \\
\hline No & $1806(48.4)$ & $1925(51.6)$ & & $493(13.2)$ & $3238(86.8)$ & \\
\hline Statin use & & & $<.0001$ & & & 0.0001 \\
\hline Yes & $257(60.9)$ & $165(39.1)$ & & $86(20.4)$ & $336(79.6)$ & \\
\hline No & $1784(48.7)$ & $1880(51.3)$ & & $492(13.4)$ & $3172(86.6)$ & \\
\hline Diuretics use & & & 0.0026 & & & 0.0098 \\
\hline Yes & $266(56.5)$ & $205(43.5)$ & & $85(18.1)$ & $386(81.9)$ & \\
\hline No & $1775(49.1)$ & $1840(50.9)$ & & $493(13.6)$ & $3122(86.4)$ & \\
\hline
\end{tabular}

Footnote: 76 matched individuals had missing information on medication use. Row percentages are reported.

Table 3: Odds Ratio of the association between cardiovascular disease and incident diabetes 


\begin{tabular}{|c|c|c|c|c|}
\hline & \multicolumn{4}{|c|}{ Odds Ratios (95\% Confidence Interval) } \\
\hline & $\begin{array}{l}\text { Self-reported CVD matched } \\
\text { model }\end{array}$ & $\begin{array}{l}\text { ECG-defined CVD matched } \\
\text { model }\end{array}$ & $\begin{array}{l}\text { Self-reported } \\
\text { CVD }\end{array}$ & $\begin{array}{l}\text { ECG-defined CVD multivariable } \\
\text { model }\end{array}$ \\
\hline & $(\mathrm{N}=4162)$ & $(\mathrm{N}=1182)$ & $\begin{array}{l}\text { multivariable } \\
\text { model }\end{array}$ & $(\mathrm{N}=8677)$ \\
\hline & & & $(\mathrm{N}=8677)$ & \\
\hline \multicolumn{5}{|l|}{$\begin{array}{l}\text { Cardiovascular } \\
\text { disease }\end{array}$} \\
\hline Yes & $1.28(1.07,1.52)$ & $1.39(1.01,1.93)$ & $1.18(0.93,1.49)$ & $1.33(0.94,1.89)$ \\
\hline No & 1.00 & 1.00 & 1.00 & 1.00 \\
\hline Mediators & Proportion mediated (\%) & & & \\
\hline Beta-blockers & 31 & & & \\
\hline Statins & 24 & & & \\
\hline Diuretics & 8 & & & \\
\hline
\end{tabular}

Footnote: Self-reported CVD matched model was unweighted and adjusted for sex and follow-up time between Visit 1 and Visit 2. ECGdefined CVD matched model was unweighted and adjusted for age, AHEI2010, and follow-up time between Visit 1 and Visit 2. Multivariable models were weighted and adjusted for covariates in Table 1 and follow-up time between Visit 1 and Visit 2.

\section{Figures}




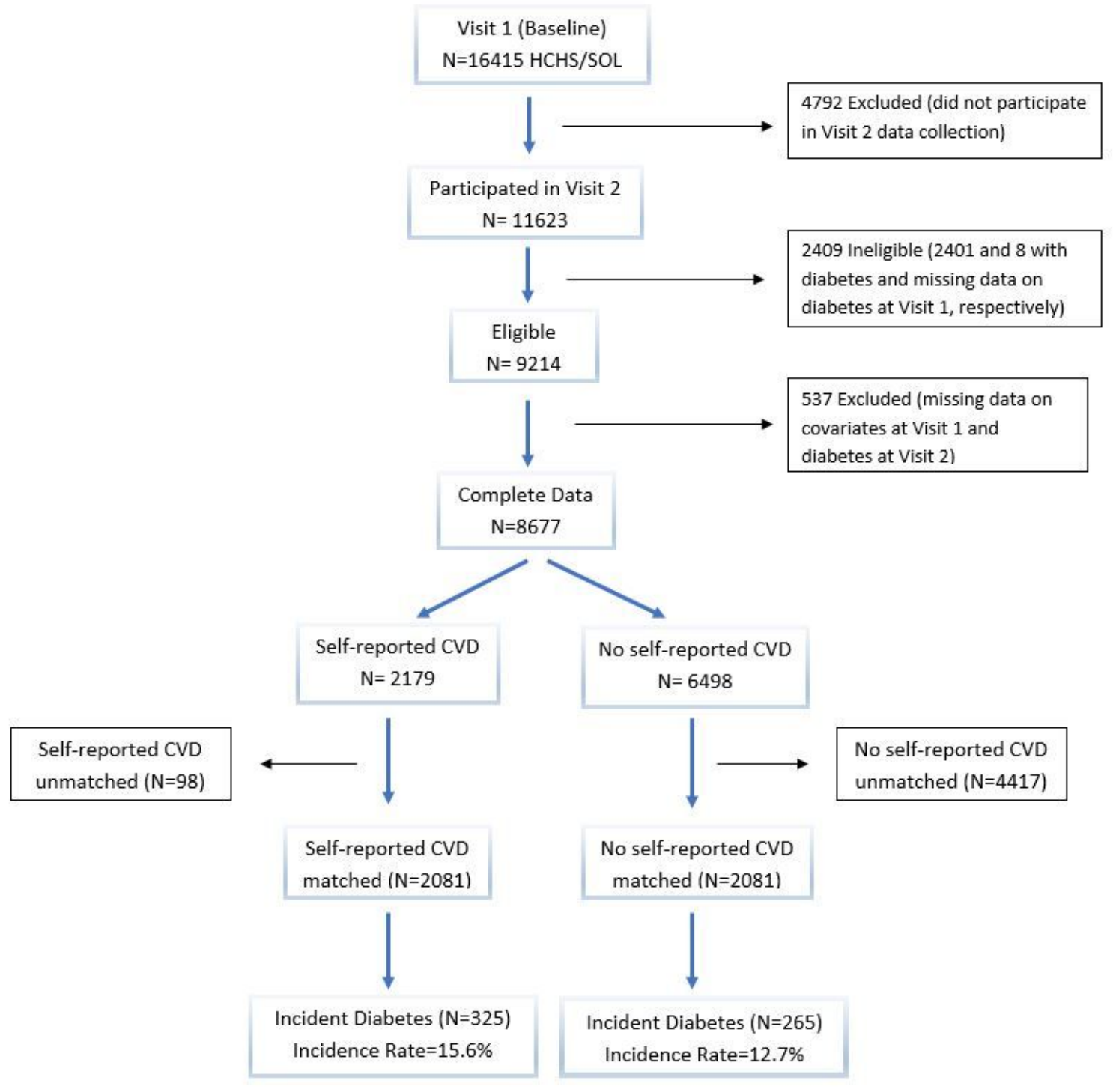

Figure 1

Flowchart of study population selection 


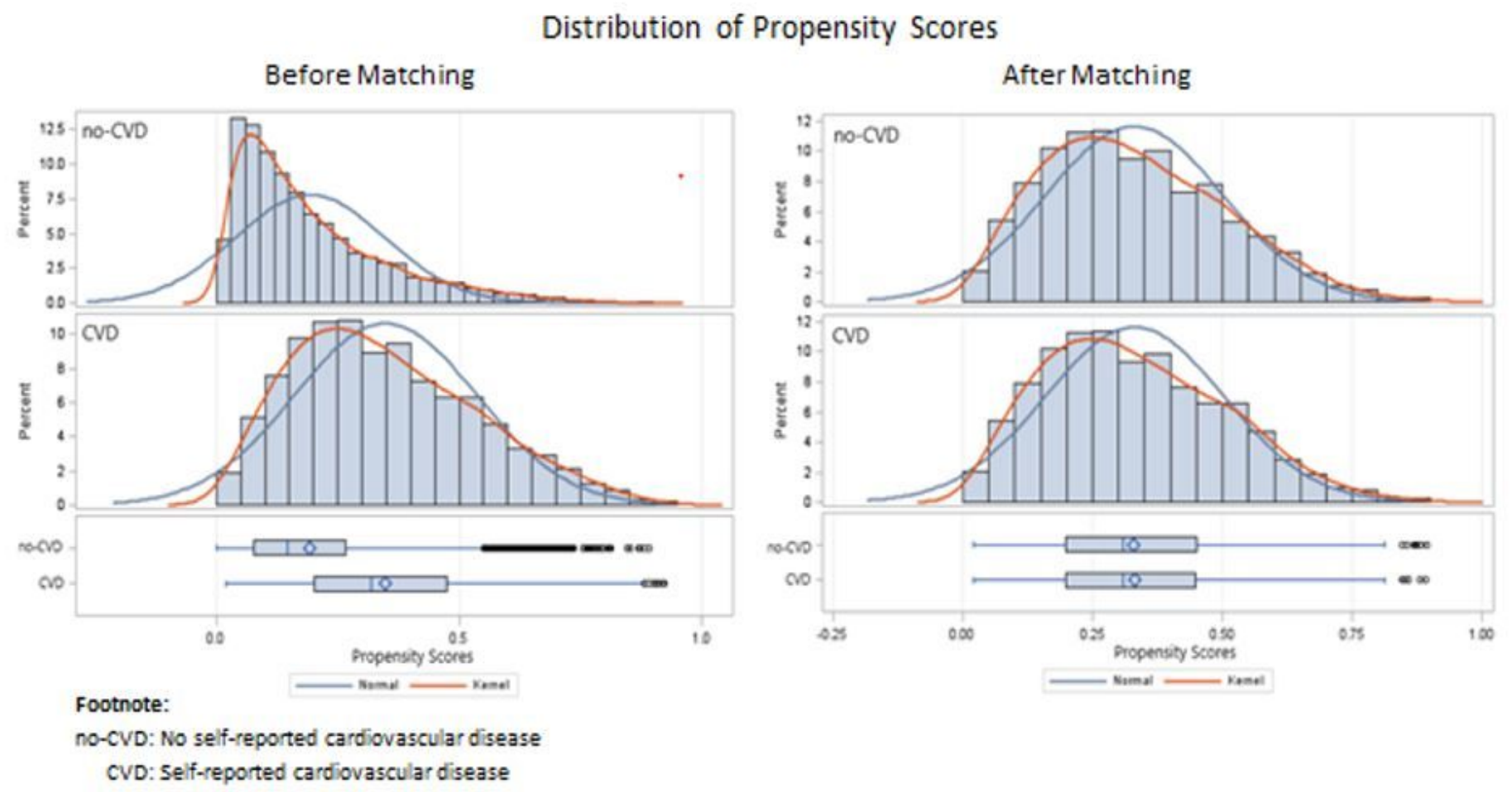

Figure 2

Propensity scores for participants with and without self-reported cardiovascular disease 